\title{
PENGARUH PENGETAHUAN MENGENAI 6 SASARAN KESELAMATAN PASIEN YANG DILAKUKAN PERAWAT DI RUMAH SAKIT
}

\author{
Pebi Septrian Sari \\ febi.septrian03@gmail.com
}

\section{LATAR BELAKANG}

Keselamatan (safety) telah menjadi isu global termasuk juga untuk Rumah Sakit. Rumah sakit merupakan salah satu institusi pelayanan kesehatan yang memiliki fungsi penting dalam meningkatkan derajat kesehatan masyarakat sehingga akan ada tuntutan untuk selalu meningkatkan mutu pelayanan yang diberikan dengan siap memberikan pelayanan pasien selama 24 jam. Rumah sakit sebagai institusi pelayanan bagi masyarakat dengan memiliki karakteristik tersendiri harus tetap mampu meningkatkan pelayanan yang bermutu dan terjangkau oleh masyarakat agar terwujudnya derajat kesehatan yang setinggi-tingginya. Dijelaskan dalam Undang-Undang RI No.44 tahun 2009 menjelaskan bahwa Rumah Sakit wajib memberikan hak pasien memperoleh keamanan dan keselamatan selama dalam perawatan di Rumah Sakit.

Keselamatan pasien (patient safety) merupakan suatu variabel untuk mengukur dan mengevaluasi kualitas pelayanan keperawatan yang berdampak terhadap pelayanan kesehatan. Keselamatan pasien merupakan suatu sistem dimana rumah sakit membuat asuhan pasien lebih aman yang meliputi asesmen risiko, identifikasi dan pengelolaan hal yang berhubungan dengan resiko pasien, pelaporan dan analisis insiden, kemampuan belajar dari insiden dan tindak lanjutnya serta implementasi solusi untuk menimalkan timbulnya risiko dan mencegah terjadinya cedera yang disebabkan oleh kesalahan akibat melaksanakan suatu tindakan atau tidak mengambil tindakan yang seharusnya diambil (Kemenkes, 2011).

Keselamatan pasien suatu sistem yang sangat dibutuhkan dan dengan adanya sistem ini diharapkan dapat meminimalisir kesalahan dalam penanganan pasien baik pada pasien UGD maupun rawat inap. Perawat berperan dalam keselamatan pasien di rumah sakit agar terwujudnya sasaran keselamatan pasien. Pengalaman perawat dalam menjamin keselamatan pasien dapat menjadi bagian terpenting untuk mewujudkan sistem yang dapat meminimalisir kesalahan dalam penanganan kepada pasien. 
Sasaran keselamatan pasien merupakan syarat untuk diterapkan di semua rumah sakit yang diakreditas oleh komisi akreditas rumah sakit. Sistem Akreditasi Rumah Sakit (KARS) versi 2012 menjelaskan bahwa seluruh kegiatan pelayanan dirumah sakit harus memberikan pelayanan yang memenuhi standar kualitas serta jaminan rasa aman dan perlindungan terhadap dampak pelayanan yang diberikan dalam rangka memenuhi hak-hak masyarakat akan pelayanan yang berkualitas serta aman. Sasaran Keselamatan Pasien (SKP) menjadi indikator standar dasar yang utama dalam penilaian Akreditasi Rumah Sakit versi 2012.

Sasaran keselamatan pasien yang dilakukan sangat berpengaruh dalam hal pengetahuan. Didalam sasaran keselamatan pasien ini melibatkan peran organisasi kesehatan dan peran pemberi pelayanan kesehatan termasuk perawat. Perawat merupakan petugas kesehatan yang mempunyai peranan sangat penting dalam menentukan mutu pelayanan kesehatan dimana perawat memiliki peran utama dalam meningkatkan dan mempertahankan kesehatan klien dengan mendorong klien untuk lebih proaktif jika membutuhkan pelayanan selama menjalani perawatan.

\section{METODE}

Metode yang digunakan pada penulisan ini menggunakan metode literature review atau studi literatur dengan cara menganalisis dan melakukan eksplorasi terhadap bahan kajian yang berfokus pada pokok pembahasan yang berhubungan dengan sasaran keselamatan pasien yang dilakukan oleh perawar di rumah sakit. Penulisan ini menggunakan sumber referensi berupa jurnal, artikel, textbook, e-book yang relevan dan terpercaya. Jurnal yang dipakai merupakan jurnal yang diterbitkan dalam 10 tahun terakhir.

\section{HASIL}

Hasil dari melakukan proses analisis terhadap sumber, telah didapati bahwa keselamatan pasien merupakan hal penting yang harus dilakukan oleh setiap perawat di rumah sakit. Keselamatan pasien ini didasari oleh adanya sasaran keselamatan pasien yang telah ditetapkan oleh setiap rumah sakit. Ada 6 sasaran di dalam rumah sakit yang mendukung keselamatan pasien yaitu ketepatan identifikasi pasien, peningkatan komunikasi yang efektif, peningkatan keamanan obat yang perlu diwaspadai, kepastian tepat lokasi, tepat prosedur, tepat pasien operasi, pengurangan resiko infeksi terkait layanan kesehatan dan pengurangan resiko pasien jatuh. Selain itu, perawat telah dapat melakukan keenam sasaran di dalam rumah sakit 
dengan baik walaupun masih belum dilakukan dengan optimal, tetapi secara keseluruhan perawat telah melakukan ketepatan identifikasi pasien dan komunikasi yang efektif.

Penelitian terhadap pemahaman perawat dalam melaksanakan sasaran keselamatan pasien mendapatkan hasil bahwa perawat telah memahami setiap bagian untuk melaksanakan sasaran keselamatan pada pasien dengan selalu menerapkan pada pasien dan mengevaluasi setiap kesalahan dalam melakukan keselamatan pada pasien. Perawat akan selalu memiliki peran yang penting secara terus menerus dengan mempromosikan perawatan yang aman sebagai satu - satunya kunci keberhasilan terciptanya keselamatan pasien.

\section{PEMBAHASAN}

Keselamatan pasien adalah suatu variabel untuk mengukur dan mengevaluasi kualitas pelayanan keperawatan yang berdampak terhadap pelayanan kesehatan. Keselamatan pasien melibatkan peran organisasi kesehatan yaitu rumah sakit dan peran pemberi pelayanan kesehatan termasuk perawat. Keselamatan pasien bagi perawat tidak hanya sebagai pedoman tentang apa yang seharusnya dilakukan, namun keselamatan pasien merupakan komitmen yang tertuang dalam kode etik perawat dalam memberikan pelayanan yang aman, sesuai kompetensi dan berlandaskan kode etik bagi pasien. Perilaku yang terbentuk pada individu dipengaruhi oleh persepsi individu berupa pengetahuan dan keyakinan terhadap suatu objek.

Pengetahuan merupakan hasil "tahu" dan ini terjadi setelah seseorang melakukan penginderaan terhadap suatu objek tertentu. Pengetahuan ini merupakan hal yang dominan yang sangat penting untuk terbentuknya tindakan seseorang, dari pengalaman beberapa penelitian ternyata tindakan yang tidak didasari pengetahuan yang baik, tidak akan menghasilkan hasil yang baik. Pengetahuan seseorang erat hubungannya dengan tindakan dalam memenuhi kewajibannya sehingga pendidikan sangat penting dalam usaha meningkatkan perawat dalam memperoleh pengetahuan.

Sebelum seseorang mengadopsi perilaku ia harus tahu terlebih dahulu tahu apa arti dan manfaat perilaku tersebut bagi dirinya atau bagi organisasi. Hal ini sesuai dengan penelitian Hesti Oktaviani (2015) yang menyatakan bawa pengetahuan perawat dengan kepatuhan perawat dalam melaksanakan SPO pencegahan resiko jatuh memilikI hubungan yang bermakna. Seorang perawat dalam memberikan asuhan keperawatan harus memiliki pengetahuan yang benar, keterampilan dan sikap untuk menangani kompleksitas perawatan kesehatan. 
Perawat sudah memiliki pengetahuan yang baik yang baik tentang penerapan SKP risiko pasien jatuh dengan skala morse . Didapatkan hasil bahwa sebagian besar perawat telah melaksanakan dengan baik program manajemen pasien jatuh yang meliputi screening, pemasangan gelang identitas resiko jatuh, edukasi pasien dan keluarga tentang menggunakan leaflet edukasi, pengelolaan pasien resiko jatuh, penanganan pasien jatuh dan pelaporan insiden. Namun di sisi lain masih juga didapatkan perawat masih memiliki pengetahuan yang kurang sehingga pada penerapan 6 SKP masih ada beberapa point yang tidak dilaksanakan. Hal ini disebabkan karena minimnya pelatihan dan evaluasi tentang penerapan 6 SKP. Pelatihan merupakan salah satu cara yang ditempuh untuk meningkatkan pengetahuan. Salah satu cara meningkatkan pengetahuan yang berguna untuk memperbaiki kinerja perawat dalam mencapai hasil kerja yang ditetapkan demi keselamatan dan kepuasan pasien dengan melakukan pelatihan secara rutin

Sasaran keselamatan pasien merupakan syarat untuk diterapkan di semua rumah sakit yang diakreditas oleh komisi akreditas rumah sakit. Sasaran keselamatan pasien meliputi 6 sasaran yaitu:

1. ketepatan identifikasi pasien

Proses identifikasi pasien dilakukan sejak dari awal pasien masuk rumah sakit dan akan selalu dikonfirmasi dalam segala proses di rumah sakit. Pada pasien yang baru masuk, telah diberikan gelang identitas. Pemberian gelang tersebut dapat memudahkan perawat dalam proses identifikasi pasien. Cara tersebut telah sesuai dengan prosedur yang ditetapkan oleh menteri kesehatan dalam Permenkes No. 1691 Tahun 2011 tentang sasaran I (pertama) keselamatan pasien di rumah sakit bahwa sedikitnya terdapat dua cara untuk identifikasi seorang pasien, seperti nama pasien, nomor rekam medis, tanggal lahir, gelang identitas pasien dengan bar-code, dan lain-lain (Kemenkes RI, 2011). Dan proses identifikasi pasien yang dilakukan perawat dengan bertanya kepada pasien sebelum melakukan tindakan dengan menyebutkan namanya.

\section{2. peningkatan komunikasi yang efektif}

Rumah sakit wajib menerapkan standar keselamatan pasien dan wajib mengupayakan pemenuhan keselamatan pasien. Salah satunya adalah peningkatan komunikasi yang efektif. Komunikasi adalah penyebab pertama masalah keselamatan pasien. Komunikasi yang tepat, akurat, lengkap, jelas, dan dipahami oleh pasien akan mengurangi kesalahan. untuk 
meningkatkan komunikasi efektif, digunakan teknik SBAR yang telah menjadi standar untuk berkomunikasi dalam situasi perawatan, catatan perkembangan pasien juga ditulis menggunakan format SBAR, yang terdiri atas situation atau kondisi pasien, background atau latar belakang kondisi pasien, assessment atau hasil pengkajian dan pemeriksaan, dan recommendation atau tindakan yang diberikan.

3. peningkatan keamanan obat yang perlu diwaspadai,

Salah satu tindakan yang mengancam keselamatan pasien adalah kesalahan pemberian obat yang dilakukan oleh perawat. Penerapan delapan benar dalam menunjang keselamatan pasien yaitu: benar pasien, benar obat, benar dosis, benar waktu, benar cara atau route pemberian, benar dokumentasi, benar informasi, dan benar pengkajian juga sudah diterapkan. Menurut Kemenkes (2011), obat-obatan menjadi bagian dari rencana pengobatan pasien, manajemen RS harus berperan secara kritis untuk memastikan keselamatan pasien. kewaspadaan terhadap obat-obat yang tingkat bahayanya tinggi harus ditunjukkan dengan menyimpannya di tempat khusus dan tidak di setiap ruangan. Yang mencirikan obat high alert adalah obat yang konsentrasinya tinggi sehingga dalam penggunaannya biasanya harus diencerkan terlebih dahulu, dalam pemberian melalui intravena biasanya diberikan melalui kateter IV ukuran 20. high alert seperti $\mathrm{KCl}, \mathrm{MgSO}$, dan Dextrose 40. Obat-obatan yang sering disebutkan dalam isu keselamatan pasien adalah pemberian elektrolit konsentrat secara tidak sengaja .n obat - obat high alert akan diberikan stiker khusus warna merah bertuliskan high alert, kemudian disimpan di dalam troli emergency, dan tidak disediakan di ruangan secara sembarangan.

4. kepastian tepat lokasi, tepat prosedur, tepat pasien operasi

Sasaran keselamatan pasien yang keempat yaitu kepastian tepat lokasi, tepat prosedur, tepat pasien operasi, yaitu: Memverifikasi lokasi, prosedur, dan pasien yang benar, memastikanbahwa semua dokumen, foto (imaging), hasil pemeriksaan yang relevan sudah tersedia dan diberi label yang baik dan sudah dipampang, menandai lokasi operasi dilakukan atas satu pada tanda yang dapat dikenali dan perlu melibatkan pasien. Penandaan lokasi operasi bukan merupakan kewenangan perawat, melainkan kewenangan dokter operator, sehingga peran mereka dalam memastikan benar letak adalah mengingatkan dokter untuk melakukan penandaan dan menyediakan peralatannya seperti spidol. 
5. pengurangan resiko infeksi terkait layanan kesehatan dan

Rumah sakit merupakan tempat yang rentan terjadi infeksi nosokomial atau infeksi baru selama perawatan cara untuk mengurangi risiko infeksi adalah melalui cuci tangan . Ada lima waktu cuci tangan atau disebut dengan five moment, yaitu sebelum ke pasien, setelah dari pasien, setelah melakukan tindakan aseptic, setelah terkena cairan pasien, dan setelah dari lingkungan pasien. Dan menggunakan alat pelindung diri (APD), seperti: Sarung tangan, masker, tutup kepala, jas, sepatu pelindung, kacamata pelindung.

Hambatan dalam melakukan cuci tangan adalah hambatan individu atau personal seperti perilaku/kebiasaan, termasuk lupa. Perawat harus bisa berusaha membiasakan dan merubah mindset bahwa cuci tangan bukan semata - mata untuk mesukseskan program rumah sakit, tapi juga untuk kebaikan diri sendiri agar tidak tertular penyakit dari rumah sakit. Meningkatkan kepatuhan dalam mencuci tangan adalah terapi untuk membentuk kebiasaan dimana salah satu prosesnya membentuk pola pikir.

6. pengurangan resiko pasien jatuh

Mengingat risiko pasien jatuh sangat besar maka sebagai perawat perlu memikirkan berbagai cara untuk mengurangi terjadinya hal tersebut. Hal ini dilakukan dengan tujuan pasien tidak perlu di rawat di Rumah Sakit lebih lama akibat komplikasi jatuh. Sehingga pasien yang diketahui berisiko jatuh, maka pasien akan diberikan penanda yaitu kancing kuning bertuliskan fall risk yang disematkan di gelang pasien. cara untuk mencegah risiko jatuh adalah dengan melakukan pengkajian risiko jatuh. Format yang digunakan adalah morse fall scale, dimana terdapat 6 komponen yaitu riwayat jatuh, diagnosis penyakit, bantuan berjalan, terapi intravena, gaya berjalan, dan status mental.

Intervensi yang dapat dilakukan perawat terkait risiko jatuh seperti memasang pengaman samping bed dan memperhatikan lingkungan sekitar yang menyebabkan pasien jatuh, mendampingi pasien saat mobilisasi, serta mengedukasi keluarga tentang risiko jatuh yang dialami pasien.

Kesalahan yang mengakibatkan pasien cedera dapat berupa ketidaktepatan identifikasi pasien yang berakibat kesalahan atau keterlambatan diagnosis, kegagalan dalam bertindak, kesalahan pengobatan, dan kesalahan dosis atau metode dalam pemberian obat. Salah satu sasaran keselamatan pasien adalah tercapainya pengurngan resiko infeksi terkait pelayanan kesehatan. Infeksi adalah inivsai tubuh oleh pathogen atau mikroorganisme yang mampu 
menyebabkan sakit. Rumah sakit merupakan salah satu tempat yang paling mungkin rentan mendapat infeksi karena mengandung populasi mikroorganisme yang sangat tinggi dengan jenis virus yang mungkin resisten terhadap antibiotik (Potter \& Perry, 2005). Sasaran keselamatan pasien lainnya yang perlu diperhatikan untuk menghindari cedera pada pasien berupa peningkatan keamanan obat yang perlu diwaspadai, pengurangan resiko infeksi terkait pelayanan kesehatan, dan pengurangan resiko jatuh.

Perawat dalam memberikan asuhan keperawatan kepada pasien harus menerapkan keselamatan pasien. Perawat harus melibatkan kognitif, afektif, dan tindakan yang mengutamakan keselamatan pasien. Perawat dalam memberikan asuhan keperawatan harus penuh dengan kepedulian. salah satu tujuan pentingnya adalah mencegah dan mengurangi terjadinya insiden keselamatan pasien. Perilaku perawat yang tidak menjaga keselamatan akan berkontribusi terhadap insiden keselamatan pasien. Perawat yang tidak memilki kesadaran terhadap situasi yang cepat memburuk gagal mengenali apa yang terjadi dan mengabaikan informasi klinis penting yang terjadi pada pasien dapat mengancam keselamatan pasien.

\section{PENUTUP}

Pengetahuan perawat didukung dengan adanya 6 sasaran keselamatan pasien yaitu identifikasi pasien, peningkatan komunikasi yang efektif, peningkatan keamanan obat yang perlu diwaspadai, kepastian tepat lokasi, tepat prosedur, tepat pasien operasi, pengurangan resiko infeksi terkait layanan kesehatan dan pengurangan resiko pasien jatuh. Pelaksanaan sasaran keselamatan pasien masih menemukan berbagai hambatan dikarenakan perawat yang masih belum sepenuhnya memahami tentang sasaran keselamatan pasien. Keselamatan pasien sangat diutamakan di dalam rumah sakit khususnya ditangani oleh perawat. Dan setiap rumah sakit wajib mengupayakan pemenuhan sasaran keselamatan pasien karena hal ini merupakan syarat yang harus diterapkan rumah sakit yang telah diakreditas oleh komisi akreditas rumah sakit.

\section{DAFTAR PUSTAKA :}

Kemenkes RI. (2011), Standar Akreditasi Rumah Sakit, Kerjasama Direktorat Jenderal Bina Upaya Kesehatan Kementerian Kesehatan Republik Indonesia dengan Komisi Akreditasi Rumah Sakit (KARS), Jakarta.

Cahyono, A. 2015. Hubungan Karakteristik Dan Tingkat Pengetahuan Perawat Terhadap Pengelolaan Keselamatan Pasien Di Rumah Sakit. Jurnal Ilmiah WIDYA. Vol 1(1). 
Lombogia, A., Rottie, J \& Karundeng, M . 2016. Hubungan Perilaku Dengan Kemampuan Perawat Dalam Melaksanakan Keselamatan Pasien (Patient Safety) Di Ruang Akut Instalasi Gawat Darurat RSUP PROF.DR. R. D. Kandou Manado. e-journal Keperawatan. Vol 4(2). 18

Keles, A. W., Kandou, G. D., \& Tilaar, Ch. R. 2015. Analisis Pelaksanaan Standar Sasaran Keselamatan Pasien Di Unit Gawat Darurat RSUD Dr. Sam Ratulangi Tondano Sesuai Dengan Akreditas Rumah Sakit Versi 2012. Jikmu. Vol 5(2). 250-259

Setiyani, D, M., Zuhrotunida \& Syahridal. 2016. Implementasi Sasaran Keselamatan Pasien Di Ruang Rawat Inap RSU Kabupaten Tangerang. JKFT. No.2

Isnaini, M, N \& Rofii, M. 2014. Pengalaman Perawat Pelaksana Dalam Menerapkan Kesamatan Pasien. Jurnal Managemen Keperawayan. Vol 2(1). 30-37

Prambudi, D,W,Y., Sutriningsih, A \& Yasin, D,F,D . 2018. Faktor-faktor Yang Mempengaruhi Perawat Dalam Penerapan 6 SKP ( Sasaran Keselamatan Pasien) Pada Akreditas JCI (Joint Commission International) Di Ruang Rawat Inap Rumah Sakit Panti Waluya Malang. Nursing News. Vol 3(1). 729-747

Neri, A, R., Lestari, Y \& Yetti, H. 2018. Analisis Sasaran Keselamatan Pasien Di Rawat Inap Rumah Sakit Umum Daerah Padang Pariaman. Jurnal Kesehatan Andalas. 7

Yusuf, M. 2017. Penerapan Patient Safety Di Ruang Rawat Inap Rumah Sakit Umum Daerah Dr. Zainoel Abidin. Jurnal Ilmu Keperawatan. Vol 5(1). 84-85

Harus, D, B \& Sutriningsih, A. 2015. Pengetahuan Perawat Tentang Keselamatan Pasien Dengan Pelaksanaan Prosedur Keselamatan Pasien Rumah Sakit (KPRS) Di Rumah Sakit Panti Waluya Sawahan Malang. Jurnal CARE. Vol 3(1). 25-32

Simamora, R. H. (2018). Buku ajar keselamatan pasien melalui timbang terima pasien berbasis komunikasi efektif: SBAR. Medan: USUpress.

Simamora, R. H. (2020). Learning of Patient Identification in Patient Safety Programs Through Clinical Preceptor Models. Medico Legal Update, 20(3), 553-556. 